\title{
Barodak and Construction of Sumbawanese Women
}

\author{
Wilda Nurhayatun \\ Mataram University \\ Mataram, Indonesia \\ wildanurhayatuns@gmail.com
}

\begin{abstract}
This paper discusses symbolic meanings of tools, materials, and the processions in Sumbawanese Barodak events. For this purpose, Koentjaraningrat's symbolic values are used in order to analyse the symbolic meanings behind the tools and the materials used in the procession. The data of this study are in the form of verbal expressions about the symbolic meanings and they were collected by using interview with ina' odak (the beautifying mothers), the brides, the grooms and the participants in the events. The study finds that the tools, the materials and the processions carry with them the symbolic meanings essential for the construction of the expected characters and the required attitudes of male and female Sumbawanese people.
\end{abstract}

Keywords—women identity; marriage tradition; beauty

\section{INTRODUCTION}

Essentially, every country possesses its own cultures and languages that distinguish one country to another. In Indonesia, there are thousands of cultures and languages that shared among almost thousands ethnic communities throughout 17000 islands from Sabang to Merauke. However, the richness of cultures and languages in Indonesia is one out of several unique characteristics of Indonesia that is wellknown by the world through the term "unity in diversity". Further, Wardhaugh (2006, p. 1) proposes that language is what the members of certain community speak. In other word, language entails as one out of some products of culture that exactly different from one ethnic community to others. In regard to culture, (Becker, 182 in Baecker, 1997, p. 2) asserts that culture is a shared understanding developed situations where all orientation relates to how others orientate to the situation. In other word, culture refers to human's reaction towards certain situations that approved by the each members of ethnic community. Moreover, Kroeber and Kluckhohn (1952, p. 85) in Aso et. al (2016, p. 51) state that culture consists of patterns, explicit and implicit, of and for behavior acquired and transmitted by the symbols, constituting the distinctive achievement of human group, including their embodiment in artifacts. From this stand point, it can be stated that culture commonly uses holy symbols that denotes any explicit and implicit behaviors towards certain situations.

In relation to culture, symbol constitutes as a pattern of culture used to represents certain behavior based on the law that has been made by the ancestors of each ethnic community. Commonly, the symbol of culture mostly comes from the religion value. Further, symbol is the object or something that suggests to something else that represents in neat and logical fashion (Pierce, 1966). Thus, symbol and culture are two inseparable things that are related to one another in maintaining human's way of life.

Basically, Indonesia entails 17000 islands that spread out from Sabang to Merauke. Besides, each island has several ethnic communities which possess its own identity and shared different cultures and languages, one of which is Sumbawa Island. Sumbawa is an island which located between Lombok and Flores islands. In this case, Sumbawa island is divided into two ethnic communities, namely Samawa (the name of Sumbawanese ethnic) and Mbojo (the name of Bimanese ethnic). In specific, ethnicity refers to certain community in Indonesia who lived in the same place, share the same language and culture (Goebel, 2013, p. 1). Further, both of these ethnic communities possess its own culture and language that they shared among each members of their community.

Samawa or Sumbawa ethnic community consists of 500.000 people that spread out from Taliwang (which is the very west side of Sumbawa Barat regency) to Empang (which is the very east side of Sumbawa Besar regency). In addition, Sumbawanese ethnic community communicates and shares information by using Sumbawanese language (in Sumbawanese "Basa Samawa"). Moreover, the majority of Samawa or Sumbawanese ethnic group is Muslim, whereas the rest are Hindu and Christian. In relation to culture, Samawa culture represents various kinds of events and characteristics, dances (Tanjung Menangis and Nguri dances), foods (Sepat, Singang and Gecok), music instruments (Sarune and Satong Serek) as well as martial (Karaci and Barumpuk) that has its own positive values toward human's life. In this case, the researcher focuses on one out of event in wedding ceremony of Sumbawa ethnic community, called barodak. Therefore, this paper aims to discuss symbolic meanings of tools, materials, and the processions in Sumbawanese Barodak events.

\section{LITERATURE REVIEW}

\section{A. Culture}

Basically, culture is defined as the way of life that used by particular societies or groups which comprises several aspects like beliefs, habits, arts, languages, custom, moral and social values. In fact, each ethnic community possesses its own culture used as the identity that differentiate them with another culture. In other words, culture is a result of taste, intention, 
thought of human that approved and believed by the members of ethnic community (Koentjaraningrat in Elizabeth, 2012, p. 18). In addition, Kroeber and Kluckhohn (1952, p. 85) propose that culture refers to all things, institutions, material objects, typical reactions to situations, which characterize a people and distinguish them from other peoples. Thus, it can be sum up that culture is human's attitudes, beliefs and behaviour toward conditions and situations which then becoming the way of life which is shared by an ethnic community that distinguishes one community to another.

Culture is simply defined as the norms that are used by particular societies as the way of life which comprises beliefs, habits, arts, languages, custom, moral and social values. Furthermore, Birukou and Blanzieri (2009, p. 2) add a brief explanation about the definition of culture which means the whole complex of traditional behaviors which has been developed by the human race and is successively learned by each generation. Every society who dwelled in the particular place has its own culture. Furthermore, Spencer (2012, p. 15) states that culture is descriptive, not evaluative concept. In other words, each culture that possessed by certain society is equal to one another, in which there is no the advance or the backwards and the good and the bad culture.

In regard to culture, Sumbawanese ethnic community possesses numbers of culture, such as dances, foods, drinks, arts, customs, habits, conventions, tools and moral values which then constitute to be the identity of the group. Further, the traditional dances of Sumbawa are Nguri and Tanjung Menangis dances. Besides, traditional foods possessed by Sumbawa ethnic community are Sepat, Singang, Gecok. In addition, Sumbawa also possessed its own traditional drink which is honey. Sumbawa's honey is well-known and commonly becomes one of the souvenirs of Sumbawa. Besides, there are some traditional arts owned by Sumbawanese ethnic group, such as Karaci and Barempuk that constitute as Sumbawanese martial arts. Moreover, the customs of Sumbawanese are comprises of some ceremonies, such as the custom of marriage and the custom of circumcision.

\section{B. Symbol}

The term symbol is highly related to culture. In simple way, culture also possesses another important pattern, called symbol. In this case, symbol refers to any objects or actions that have its own value to describe something. Munn (1986, p. 7) adds opinion that "symbolic" can refers to any cultural form of whatever kind or complexity of meaning, and to the immediate manipulation and working out of meaningful forms within specific activities. In this view, symbol constitutes as a cultural form that represents its own value and meaning.

Further, symbol is the object or something that suggests to something else that represents in neat and logical fashion (Pierce, 1966). Therefore, symbol is considered as one out of some pivotal pattern in culture that performs as well as represents the meaning of an event or an action.

\section{Barodak}

Marriage is the sacred process of the unity of both man and woman that is legitimate based on the law of religion and the country. Therefore, the members of Sumbawa ethnic community believe that the processions of the wedding have to be done as sacred as possible in effort to ask Allah SWT to always protect and bless the family. In Sumbawa, there are some events that have to hold by the family of both the bride and the groom, namely bajajag, bakatoan, basaputis, bada', nyorong, barodak, nikah, and reception. Further, the members of Sumbawanese ethnic community believe that if one out of some events in marriage ceremony does not be done, thus the family of the bride and the groom will had a bad luck in the future.

Barodak comes from the word "odak" which means the traditional scrub. Essentially, Barodak is the procession of scrubbing the bride and the groom using odak (Sumbawanese's traditional mask). In Sumbawanese ethnic community, barodak is considered as one out of some pivotal events in marriage ceremony that have to be done before the marriage procession in order to prepare both of the bride and the groom to be faced the new journey of their life as a family physically as well as mentally. In general, Barodak leads by the one who is called as ina odak (the older sister or family of the bride). In addition, ina odak delivers the rhymes (in Sumbawanese, "lawas") that contain prayers and expectations that Allah SWT will always protect and they will live happily ever after. Moreover, the duty of ina odak in barodak procession is to scrub the bride and the groom in turn using the mask (in Sumbawanese, odak) starting from the face, neck and their hands. In addition, ina odak invites all the guests (women) to scrubbing the mask (odak) on the bride and the groom until their face and body full of mask.

\section{METHOD}

In this case, the researcher uses a method that based on the purpose of this study.

\section{A. Research Design}

Since the purpose of this paper is to discuss symbolic meanings of tools, ingredients, and procession in Sumbawanese barodak event, this paper applied a qualitative descriptive design.

\section{B. Source of Data}

The subject of the paper are informants who are give an information about Barodak event include ina' odak (the beautifying mothers), the brides, the grooms and the participants in the events. On the other hand, the object of the paper is the symbols used on Barodak event in Sumbawa.

\section{Data Collection}

The data were collected in form of verbal expression through documentation, interview and observation. Moreover, after gathered the data, the procedure of analyzed the data are by prepare the data, analyze the data and report the data. 


\section{Data Analysis}

The data were analyzed through data reduction, data display and conclusion.

\section{RESUlt AND DisCUSSION}

Barodak is an event that is held a night before the wedding ceremony done by Sumbawanese ethnic community. Hence, Barodak can solely be found in Sumbawa, due to the fact that it is one out of some customs that is only possessed by Sumbawanese culture. Therefore, barodak will never be found event in another culture in Indonesia. Actually, the aim of this Barodak event is to clean up the bodies and the souls of the bride and the groom to live the new journey of their life as a husband and wife. Moreover, Barodak also makes both of the bride and the groom's faces to be as shining as the sun.

As we know, every event requires any tools, materials and processions in order to conduct the events from the beginning until ending. Therefore, barodak event also possessed its own tools, materials and processions, as follows.

\section{A. Tools of Barodak}

The tools of barodak generally consists of several sacred tools, as follows.

1) Dila Malam (Sumbawanese traditional candle) : To symbolize a hope and a light that can always lighten the journey of the bride and the groom as a family.

2) Pangkenang (Sumbawanese traditional clothes) : To symbolize the humbleness of both the bride and the groom.

3) Kre Putih (white goods/white fabric) : To symbolize the sanctity relationship between the bride and the groom as well as both families of the bride and the groom.

4) Cendruang (traditional decorative four sides weddingplace made of from bamboo which is used by the bride and the groom to be scrubbed): To symbolize the faithfulness of the bride and the groom in every single conditions, such as in the rich and poor as well as in the health and sickness.

5) Tipar umpuk (the mat that made of 7 different fabrics): To symbolize the intimacy of the bride and the groom.

Generally, Barodak event is held in the bride's house and attended by numbers of guests. In this sense, the guests are located into two different places, the women are located inside the room whereas the men are located outside of the room. Basically, the room which is used to be the place of Barodak is decorated with Sumbawanese arts and cendruang. In specific, cendruang is traditional decorative four sides wedding-place made of from bamboo which is used by the bride and the groom to be scrubbed. Further, each sides of the cendruang is decorated with dila malam (Sumbawanese traditional candle) in order to lighten the process of the event and keep the bride and the groom far away from evils. Moreover, the floor of cendruang is decorated using Smbawanese traditional mat, called tipar umpung/samparumpuk (the mat that is made of 7 different fabrics). Along the process of conducting Barodak, both of the bride and the groom use pangkenang (Sumbawanese traditional clothes), called lamung pene. On the other hand, the outside of the room is decorated with full set of rabana and sarune (traditional musical instruments) to recite the prayers. In addition, this activity is also called sarakal which used to ask the God to always protect both of the bride and the groom along the event and the journey of their family for the rest of their life.

\section{B. Materials of Barodak}

Barodak event is totally similar to another event in other ethnic community, in which it needs the materials to conduct. Further, the materials of barodak entail certain things, as follows.

A. Odak (the scrub)

Odak (the scrub) is Sumbawanese traditional scrub used to mask the bodies of the bride and the groom in effort to lighten their faces and souls before the wedding procession. Essentially, odak made of from several materials entails bage tunung (the roasted tamarind), loto tunung (the roasted rice), buah pinang (betelnut) and sirih leafs. Each materials of odak represents its own meanings, as follows.

a) Bage tunung (the roasted tamarind) symbolizes the cleanness of the body and soul.

b) Loto tunung (the roasted rice) symbolizes the fertility and the properity.

c) Buah pinang (betelnut) symbolizes the heart-beating.

d) Din eta (sirih leafs) symbolizes the purity of the heart.

Thus, the abovementioned materials are mashed while reciting sholawat.

B. Ai kemang (the immersion water of flower)

Ai kemang (the immersion water of flower) symbolizes the tenderness of the heart.

\section{3) Pancar}

Pancar symbolizes the spirit to fight and sacrifice their own desires for the family's prosperity. Moreover, pancar also indicates that the women and the men are already taken.

4) Bête/loto kuning (yellow rice)

Bête/loto kuning (yellow rice) symbolizes the graces that showed by God to the family and to throw the evils that wants to disturb the event.

In the event of barodak, odak (the scrub) is the most pivotal thing that has to be made by the ina' odak (the beautifying mother) while reciting any prayers in order to hope Allah SWT always smoothens the events as well as the bride and the groom. Further, odak is made of several materials, some of which are bage tunung (the roasted tamarind), loto tunung (the roasted rice), din eta (sirih leafs), ai kemang (the immersion water of flowers) and others secret materials by mixing them becoming as smooth as the modern scrub. Moreover, the members of Sumbawanese ethnic community believe that each of these materials possesses highly valuable function for health and also for the souls. In addition, pancar is also take an important part in the barodak event to make the bride and the groom's fingers and toes becoming red. This process is used to distinguish the marriedmen and women with the single-men and women. Furthermore, another material needed in barodak is bete/loto 
kuning (yellow rice). This material is used by throwing the bete/loto kuning (yellow rice) to the bride and the groom along the process of barodak in order to hope Allah SWT always blessed them and protect them from evils.

\section{Procession of Barodak}

In regard to barodak event, there are several steps of the procession that have to be faced by the bride and the groom, as follows.

1) The bride and the groom are coated with kre' putih.

2) The bride and the groom are started to scrubbed.

3) The bride and the groom's fingers and toes are beautified by using pancar.

4) The bride and the groom's faces are splashed by the immersion of water.

5) Dila malam (Sumbawanese traditional candle) are being rotated near the bride and the groom's faces three times.

6) The bride and the groom have to blow up dila malam (traditional candles) together until dila malam (traditional candles) are off.

The very first thing of barodak event is the bride and the groom wear pangkenang (Sumbawanese traditional clothes), called lamung pene to indicates that the bride and the groom are ready to be scrubbed. Moreover, both of the bride and the groom have to sit on the tipar umpuk (the mat that made of 7 different fabrics) in the cendruang (traditional decorative four sides wedding-place made of from bamboo which is used by the bride and the groom to be scrubbed) surrounded by dila malam (Sumbawanese traditional candles) in each sides.

Furthermore, barodak begins with ina' odak coated both of the bride and the groom using kre' putih (white goods/white fabric). In this case, both of them are coated using kre' putih (white goods/white fabric) symbolizes that their sanctity relationship is protected by Allah SWT until death do them apart. Moreover, the next step of barodak is the bride and grooms starts to scrub by ina' odak (the beautifying mother) and numbers of close families from the bride and the groom. The process of rubbing the scrub is done by coming to the cendruang (traditional decorative four sides wedding-place made of from bamboo which is used by the bride and the groom to be scrubbed) and rub the bride and the groom in turn. In fact, the scrub is rubbed to the bride and the groom's faces and hands due to the fact that they wear pangkenang (Sumbawanese traditional clothes), called lamung pene.

In addition, the third procession of barodak is beautifying the bride and the groom's fingers and toes by using pancar. Pancar denotes the borderline between the marriage-men and the single-men in the real life. Besides, pancar also symbolizes the spirit of both the bride and the groom to fight and sacrifice their own desires for the prosperity of the family.

The other procession of barodak event is splashing the bride and the groom's face using ai kemang (the immersion water of flowers). This process believes by the members of Sumbawanese ethnic community can make the bride and the groom's faces becoming shining in their wedding day. Basically, ina odak (the beautifying mother) is the one who has authority to splash the faces of the bride and groom after being scrub using odak (Sumbawanese traditional scrub).

Moreover, ina odak (the beautifying mother) takes the dila malam (Sumbawanese traditional candles) and surrounded it three times around the bride and the groom. The process of surrounded the dila malam (Sumbawanese traditional candles) around the bride and the groom symbolizes that there is always a hope that can always lighten the journey of the bride and the groom. Further, the bride and the groom have to blow up the dila malam (Sumbawanese traditional candles) together until the candles are off to measure their cooperativeness in maintaining their new life as a family. Thus, after the dila malam (Sumbawanese traditional candle) are off, the ina odak (the beautifying mother) takes the smoke of the dila malam (Sumbawanese traditional candle) and wipe the smoke to the bride and the groom's heads that indicates that ina odak (the beautifying mother) give them advice about the marriage life.

Along the procession of barodak event, each procession is accompanied by sarakal (the prayer form with traditional musical instruments) to hope that Allah SWT protects the bride as well as the groom and to protect the solemnity of the event. Sarakal is done by the men outside the room used for barodak event.

\section{V.CONCLUSION}

Culture and language are two interrelated aspects that hierarchically holds significant role in human's life. Each culture possesses its own symbols, meanings and values that mutually agreed among the members of ethnic community. Thus, its symbol represents certain values that made by the ancestors based on the God's law. In this case, this study focuses on Sumbawanese wedding custom, especially on the barodak event that held a night before the wedding ceremony.

The finding of this study have revealed that there are several tools needed in the barodak event, which are dila malam (Sumbawanese traditional candle), pangkenang (Sumbawanese traditional clothes), kre putih (white goods/white fabric), cendruang (traditional decorative four sides wedding-place made of from bamboo which is used by the bride and the groom to be scrubbed) and Tipar umpuk (the mat that made of 7 different fabrics). Furthermore, the materials that are needed in the barodak event generally consist of four materials, namely odak (the scrub), ai kemang (the immersion water of flowers), pancar and bete/loto kuning (yellow rice). On the other hand, the procession of barodak event comprises six steps, which are the bride and groom are coated by using kre putih, the bride and the groom are started to scrub, the bride and the groom's fingers and toes are beautified by using pancar, the bride and the groom's faces are splashed by the immersion water of flowers, the bride and the groom are being surrounded by dila malam (Sumbawanese traditional candle) three times and both of the bride and the groom have to blow up the dila malam (Sumbawanese traditional candle) together.

This study concludes that the tools, the materials and the processions of barodak event in wedding custom of Sumbawa ethnic community mark that there is an equal position of both the world and the hereafter. This statement is in line with the 
motto of Sumbawa, which is Sabalong Samalewa means the equality between the needs of the world and the needs of the hereafter. From this standpoint, it is no surprise that the symbols possess by Sumbawa ethnic community are highly related to the God's mandates in every aspects of human's life.

\section{Acknowledgment}

The researcher would like to express her full-hearted gratitude to the subjects of this study, who are ina odak, the bride, the groom and the participant of barodak event as well as anyone who gave endless support to finish this paper.

\section{References}

Birokou, A, Blanzieri, B., Giorgini, P., \& Ghiungchiglia, F. (2009). A formal definitions of culture. Italy: University of Trento.

Kroeber, A. L., \& Kluckhohn, C. (1952). Culture: a critical review of concepts and definitions. Cambridge: The Museum.
Munn, N. (1986). The fame of Gawa: a symbolic study of a value transformation in a Masim (Papua New Guinea) society. Duke: Duke University Press.

Pickering, J., \& Hoeper, J. (1997). Literature (fifth Ed.). New Jersey: Prentice Hall.

Wardaugh, R. (2006). Introduction to sociolinguistic. Malden, Oxford, \& Victoria: Blackwell.

Baecker, D. (1997). The meaning of culture. Thesis Eleven, 51, 37-51. doi: 10.1177/0725513697051000004

Aso, S. M., Sujito, \& Siane (2016). A study on symbol used in So'a Para Zedhe ceremony. Jurnal Ilmiah Bahasa dan Sastra, $3 . \quad$ Retrieved from http://ejournal.unikama.ac.id/index.php/JIBS/article/down load/1155/1262

Spencer-Oatey, H. (2012). What is culture? A compilation of quotations. Retrieved from http://www.warwick.ac.uk/globalpadintercultural

Goebel, Z. (2013). The idea of ethnicity in Indonesia [Abstract]. Tilburg Papers in Culture Studies, 71, 1-34. 